\title{
Scientists bust myth that our bodies have more bacteria than human cells
}

\section{Decades-old assumption about microbiota revisited.}

\section{Alison Abbott}

08 January 2016

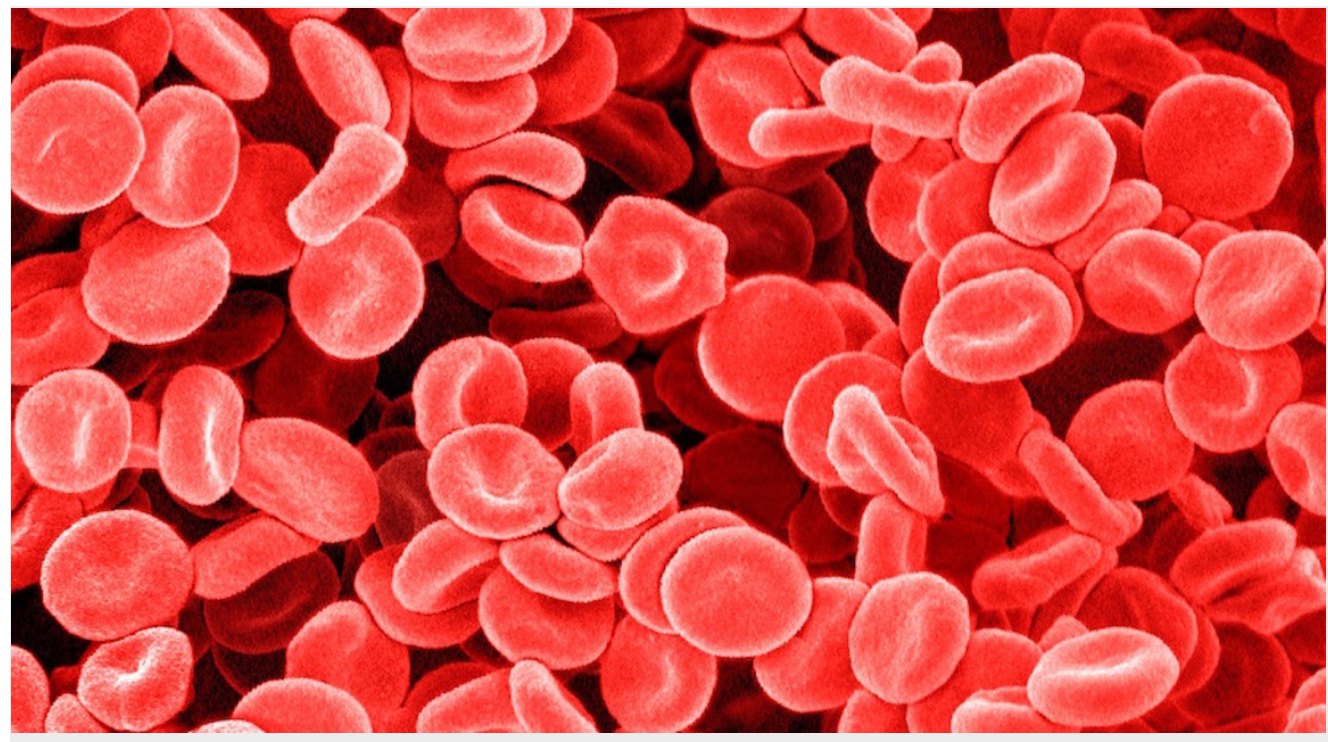

SUSUMU NISHINAGASSCIENCE PHOTO LIBRARY

Red blood cells dominate our total cell count by number (though not by mass).

It's often said that the bacteria and other microbes in our body outnumber our own cells by about ten to one. That's a myth that should be forgotten, say researchers in Israel and Canada. The ratio between resident microbes and human cells is more likely to be one-toone, they calculate.

A 'reference man' (one who is 70 kilograms, 20-30 years old and 1.7 metres tall) contains on average about 30 trillion human cells and 39 trillion bacteria, say Ron Milo and Ron Sender at the Weizmann Institute of Science in Rehovot, Israel, and Shai Fuchs at the Hospital for Sick Children in Toronto, Canada.

Those numbers are approximate - another person might have half as many or twice as many bacteria, for example — but far from the 10:1 ratio commonly assumed.

"The numbers are similar enough that each defecation event may flip the ratio to favour human cells over bacteria," they delicately conclude in a manuscript posted to the preprint server bioRxiv ${ }^{1}$.

The 10:1 myth persisted from a 1972 estimate by microbiologist Thomas Luckey, which was "elegantly performed, yet was probably never meant to be widely quoted decades later", say the paper's authors. In 2014, molecular biologist Judah Rosner at the US National Institutes of Health at Bethesda, expressed his doubts about the 10:1 claim, noting that there were very few good estimates for the numbers of human and microbial cells in the body.

Milo, Sender and Fuchs decided to re-estimate the number by reviewing a wide range of recent experimental

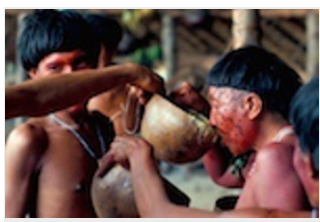

Bacteria bonanza found in remote Amazon village data in the literature, including DNA analyses to calculate cell number and magnetic-resonance imaging to calculate organ volume. The vast majority of human cells are red blood cells, they note (see 'Counting human cells'). 


\section{COUNTING HUMAN CELLS}

Most of our body's cells are small red blood cells, although fat cells and muscle cells make up the majority by mass.

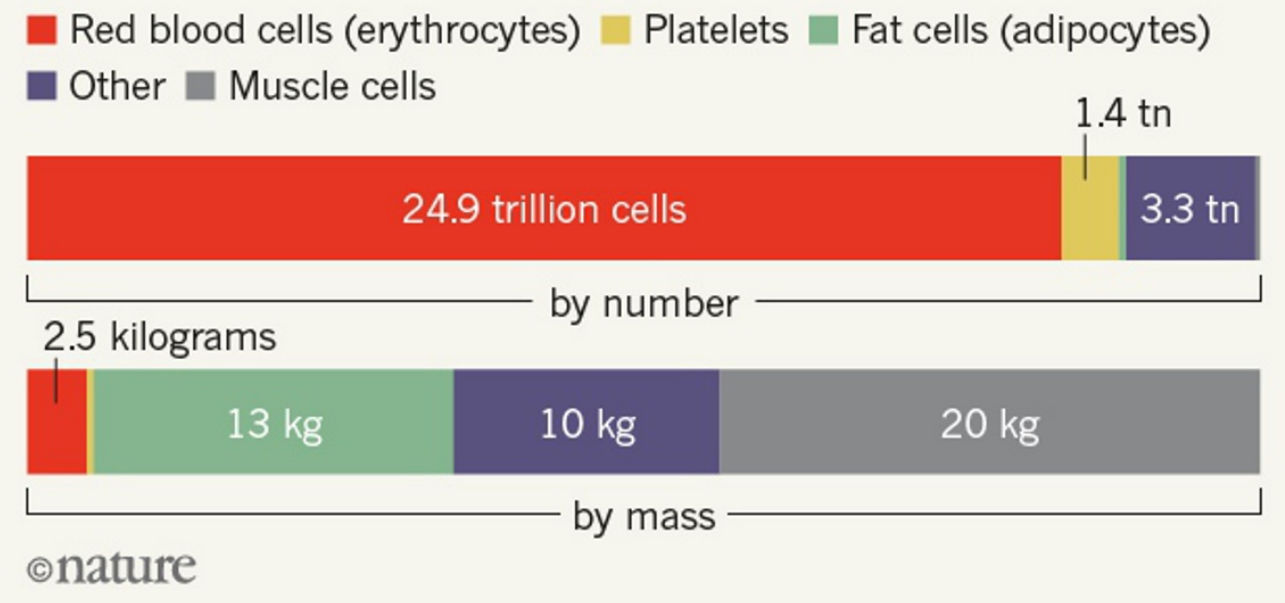

Source: Ref. 1

\section{Faecal factor}

A particular overestimate in Luckey's work relates to the proportion of bacteria in our guts, Milo and colleagues say. Luckey estimated that guts contain around $10^{14}$ bacteria, by assuming that there were $10^{11}$ bacteria in a gram of faeces, and scaling that up by the onelitre volume of the alimentary canal, which stretches from the mouth to the anus.

But most bacteria reside only in the colon (which has a volume of 0.4 litres), Milo and colleagues point out and measurements suggest that there are fewer bacteria in stool samples than Luckey thought.

Putting together these kinds of calculations, the researchers produce a ratio for microbial to human cells for the average man of 1.3:1, with a wide uncertainty. Milo declined to comment on the paper, because it is in review at a scientific journal.

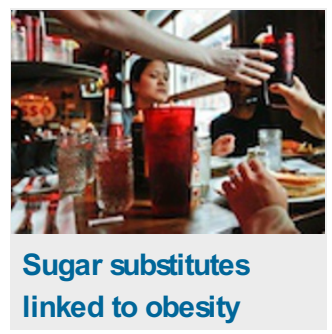

"It is good that we all now have a better estimate to quote," says Peer Bork, a bioinformatician at the European Molecular Biology Laboratory in Heidelberg, Germany, who works on the human and other complex microbiomes. "But I don't think it will actually have any biological significance."

Nature I doi:10.1038/nature.2016.19136

\section{References}

1. Sender, R., Fuchs, S. \& Milo, R. Preprint on bioRxiv http://dx.doi.org/10.1101/036103 (2015). 